Conscientious Objection through the Contrasting Lenses of Tolerance and Respect

Peer-reviewed author version

SMET, Stijn (2019) Conscientious Objection through the Contrasting Lenses of Tolerance and Respect. In: Oxford Journal of Law and Religion, 8(1), p. 93-120.

DOI: 10.1093/ojlr/rwz004

Handle: http://hdl.handle.net/1942/28436 


\title{
Conscientious Objection through the Contrasting Lenses of Tolerance and Respect
}

\author{
Stijn Smet
}

Scholars disagree on how the law should respond to conscientious objections. Among these scholars, some cast their arguments in terms of tolerance and respect. Yossi Nehushtan, for instance, favours the lens of tolerance, while John Olusegun Adenitire, among others, favours the contrasting lens of respect. In this article, I argue that we need both lenses - tolerance and respect - to make sense of how constitutional democracies (ought to) respond to conscientious objections. I begin by proposing a normative-conceptual argument, in which I map the contrasting lenses of respect and tolerance onto distinct categories of claims of conscience: rights-infringing and standard claims. I explain the normative argument with reference to conscientious objection to paying taxes, to military service, to abortion and to same-sex marriage. I then complicate the theoretical argument by discussing diverging legal responses to claims of conscience across less familiar constitutional democracies (Singapore, South Korea, Colombia, Sweden, Italy, South Africa and the Netherlands). I conclude by proposing that, quite separate from any normative disagreement on these claims, there is a practical baseline that delineates the realm of possible legal responses to conscientious objections.

Conscientious objectors challenge majoritarian decision-making by refusing to comply with general laws. Some claims of conscience, for instance against compulsory military service, are now broadly protected in constitutional democracies. But others remain deeply contested. This is especially true for conscientious objection in relation to same-sex marriage and reproductive health care. In these contexts, claims of conscience are sometimes interpreted as conservative clawbacks in the wake of liberal legislation. ${ }^{1}$ Having lost the political and legal

\footnotetext{
${ }^{1}$ Douglas NeJaime and Reva B Siegel, 'Conscience Wars: Complicity-Based Conscience Claims in Religion and Politics' (2014) 124 Yale LJ 2516, 2543 and 2553; Charles G Ngwena, 'Conscientious Objection to Abortion and Accommodating Women's Reproductive Health Rights: Reflections on a Decision of the
} 
battle on abortion and same-sex marriage, the perception goes, some religious persons have turned to rights discourse to erect new obstacles to practices they disapprove of. ${ }^{2}$

Regardless of how (un)charitably one characterizes claims of conscience, the perennial question remains: how should the law respond to conscientious objections? The answer is usually cast in terms of reasonable accommodation or proportionality analysis. ${ }^{3}$ Some scholars, however, have proposed alternative accounts by drawing on notions of tolerance and respect. ${ }^{4}$ In this journal, Yossi Nehushtan has proposed an answer from tolerance, ${ }^{5}$ which John Olusegun Adenitire has countered with a respect-based account. ${ }^{6}$ The debate between Nehushtan and Adenitire tracks a similar debate in the United States between Martha Nussbaum and Brian Leiter. ${ }^{7}$ In both debates, there is fundamental disagreement on the lens through which claims for religious exemptions should be evaluated: the lens of tolerance or the lens of respect. In this article, I argue that we need both lenses.

To Nehushtan, 'granting conscientious exemptions is best understood as the outcome of tolerance'. ${ }^{8} \mathrm{He}$ argues that when the state grants an exemption, it makes an 'adverse judgment about the conscientious objector's values or his way of balancing between values', because '[o]therwise, the exemption would have been the general rule rather than the exemption to it'. ${ }^{9}$ On Nehushtan's account, tolerance is thus the focal lens: '[i]f the state decides to grant conscientious exemptions after all [that is, regardless of its disapproval], it can be seen as tolerant'. ${ }^{10}$

John Olusegun Adenitire considers Nehushtan's view 'misguided'. ${ }^{11}$ To Adenitire, ' $[\mathrm{t}]$ he practice of conscientious exemptions is not best explained nor should it be mainly guided by the principle of toleration'. ${ }^{12}$ Adenitire invokes two arguments against tolerance-

Constitutional Court of Colombia from an African Regional Human Rights Perspective' (2014) 58 Journal of African Law 183, 206.

${ }^{2}$ NeJaime and Siegel (n 1) 2558.

${ }^{3}$ See, for instance, Bruce MacDougall and others, 'Conscientious Objection to Creating Same-Sex Unions: An International Analysis' (2012) 1 Canadian Journal of Human Rights 127, 160.

${ }^{4}$ See also Brian Leiter, Why Tolerate Religion? (Princeton University Press 2013); Martha C Nussbaum, Liberty of Conscience: In Defense of America's Tradition of Religious Equality (Basic Books 2010).

${ }^{5}$ Yossi Nehushtan, 'What Are Conscientious Exemptions Really About?' (2013) 2 Oxford Journal of Law and Religion 393.

6 John Olusegun Adenitire, 'Conscientious Exemptions: From Toleration to Neutrality; From Neutrality to Respect' (2017) 6 Oxford Journal of Law and Religion 268.

${ }^{7}$ Nussbaum (n 4); Leiter (n 4).

${ }^{8}$ Ibid at 393.

${ }^{9}$ Ibid at 396.

${ }^{10}$ Ibid.

${ }^{11}$ Adenitire (n 6) 270.

12 Ibid. 
based accounts of exemptions. First, he posits that duties of neutrality preclude judges from disapproving of a given belief. ${ }^{13}$ Hence, it is impermissible for judges to '[hold] the attitude of toleration when they grant an exemption'. ${ }^{14}$ Second, he argues that 'because the state is a complex aggregate of individuals and institutions, it is very problematic to attribute one single ... attitude to it'.$^{15}$ Adenitire here conceives of tolerance as a personal attitude. As such, he posits, it cannot be held by the state as a collective entity. Having rejected Nehushtan's tolerance-based account, Adenitire goes on to propose an alternative. He argues that the lens of respect, not tolerance, is central to understanding practices of legal exemptions for conscientious objectors. ${ }^{16}$

In this article, I enter the debate between Nehushtan and Adenitire by arguing that we need both lenses - tolerance and respect - to make sense of how constitutional democracies (ought to) engage with conscientious objections. My main argument is normative-conceptual. I map the contrasting lenses of tolerance and respect onto different categories of conscientious objection, by drawing on a variation of Douglas NeJaime's and Reva Siegel's distinction between 'standard' ${ }^{17}$ and 'complicity-based' claims of conscience. ${ }^{18} \mathrm{I}$ argue that some claims of conscience, such as against compulsory military service, should be viewed through the more permissive lens of respect. Through the lens of respect, conscientious objection is viewed in a positive light. As a result, a presumption operates in favour of protection and against restriction. By contrast, other claims of conscience - such as against abortion or same-sex marriage - should be evaluated through the more restrictive lens of tolerance. Through the lens of tolerance, conscientious objections are regarded with suspicion and disapproval. Hence, the presumption now operates against protection and in favour of restriction. The key difference between both categories of conscientious objection, justifying their analysis through contrasting lenses, is this: whereas claims of conscience in the first category do not infringe the legal rights of others, those in the latter category do. All of this is unpacked below.

The structure of the article is as follows. In Section 1, I engage with Adenitire's argument from respect and propose two possible responses to his objections against

\footnotetext{
${ }^{13}$ Ibid at 275 .

${ }^{14}$ Ibid.

${ }^{15}$ Ibid at 272.

${ }^{16}$ Ibid at $287-91$.

17 This is my terminology, as NeJaime and Siegel do not name this category of claims of conscience (that is, claims of conscience that are not complicity-based).

${ }^{18}$ NeJaime and Siegel (n 1) 2524-27.
} 
tolerance. In Section 2, I unpack the normative-conceptual argument with reference to specific instances of conscientious objection: to military service, to abortion and to same-sex marriage. In Section 3, I complicate the normative-conceptual argument through comparative analysis. I discuss diverging legal responses, across constitutional democracies, to the same instances of conscientious objection that inform the normative-conceptual argument. In relation to each of these instances, I contrast a constitutional democracy that favours the argument I propose in Section 2 to a constitutional democracy that has adopted the opposite solution. The comparative discussion deliberately eschews the "usual suspects' ${ }^{19}$ of the field the United States, Canada and the United Kingdom. Instead, I discuss legal responses to conscientious objection in less familiar jurisdictions. For conscientious objection to military service, I compare Singapore to the Republic of Korea. For conscientious objection to abortion, I compare Colombia to Sweden (and introduce Italy as a useful juxtaposition). For conscientious objection to same-sex marriage, finally, I compare South Africa to the Netherlands.

In the conclusion, I draw on the comparative analysis to identify a practical baseline composed of two factors: availability of alternative duties and frequency of objections. In their interaction, both practical factors set a bar below which conscientious exemptions cannot be granted. As a result, it is redundant to engage in normative disagreement on (dis)respect or (in)tolerance of conscientious objections. Only above the practical baseline, I will conclude, is there room for normative disagreement on exemptions for conscientious objectors. Why this is so will become clear in due course.

\section{Tolerance and Respect: Contrasting Lenses, Similar Problems}

Tolerance entails restraint, a conscious decision to not interfere with beliefs, opinions and practices of which one disapproves. As both a moral virtue and a political practice, tolerance was central to bringing about (relatively) peaceful religious co-existence in early modern Europe. Tolerance arguably remains vital to ensuring peaceful co-existence in contemporary societies marked by religious and cultural pluralism. ${ }^{20}$ In an ideal world, perhaps, everyone

\footnotetext{
${ }^{19}$ Ran Hirschl, Comparative Matters: The Renaissance of Comparative Constitutional Law (Oxford University Press 2014) 4.

${ }^{20}$ John Rawls, Political Liberalism (Expanded ed, Columbia University Press 2005) 157, 486 and 488.
} 
would treat others with respect. But in our real world, mutual tolerance may often be the best we can hope for. ${ }^{21}$

Nevertheless, tolerance has its fair share of critics. These critics target the disapproval intrinsic to tolerance and the power differential inherent in its practice. Tolerance tends to be exercised by the state or majority over a minority. The state or majority disapproves of what members of a minority believe, say or do, but nevertheless tolerates their beliefs, opinions or practices. The common objection to this situation is fairly obvious: minorities deserve more than mere toleration..$^{22}$ Martha Minow, for instance, sees liberal tolerance as 'a second-best, a kind of "putting up with" difference that falls short of genuine respect'. ${ }^{23}$ Martha Nussbaum also favours the notion of (equal) respect, rejecting tolerance as 'too grudging and weak' an attitude. ${ }^{24}$

In an article in this journal, Adenitire also argues against tolerance and for respect, but from a different vantage point. ${ }^{25}$ In his article, Adenitire posits that 'the main reason for marginalizing toleration is that in judicial practice regarding conscientious exemptions the law has committed itself to the principle of neutrality towards the content of conscientious objectors' beliefs'. ${ }^{26}$ The law therefore 'prevents judges from holding the attitude of toleration when they grant an exemption'. ${ }^{27}$ Additionally, Adenitire submits, 'because the state is a complex aggregate of individuals and institutions, it is very problematic to attribute any one single ... attitude [including that of toleration] to it without speaking metaphorically'. ${ }^{28}$ But Adenitire does more than deconstruct. He also provides an alternative. He argues that in considering claims for exemptions, lawmakers and judges should respect a range of 'principles' or 'values': pluralism, personal autonomy, liberty of conscience and

\footnotetext{
21 John Horton, 'Why the Traditional Conception of Toleration Still Matters' (2011) 14 Critical Review of International Social and Political Philosophy 289, 292, 299 and 303.

${ }^{22}$ Susan Mendus, Toleration and the Limits of Liberalism (Macmillan 1989) 159; John Horton, 'Toleration as a Virtue', in David Heyd (ed), Toleration: An Elusive Virtue (Princeton University Press 1998) 35.

${ }^{23}$ Martha Minow, 'Tolerance in an Age of Terror' (2006) 16 Southern California Interdisciplinary Law Journal $453,457$.

${ }^{24}$ Nussbaum (n 4) 24.

${ }^{25}$ I should clarify that, despite my critique in the text, I support Adenitire's general argument that 'if toleration has at all any role to play in explaining or guiding the practice of conscientious exemption, that role should be kept within rigorous boundaries' (Adenitire (n 6) 270). See references omitted for review purposes.

${ }^{26}$ Adenitire (n 6) 270.

${ }^{27}$ Ibid at 275 .

${ }^{28}$ Ibid at 272.
} 
well-being. ${ }^{29}$ Unfortunately, Adenitire does not clarify what he means by respect. This lack of clarity conceals some problems with his account.

Drawing on Stephen Darwall's work on respect, we can hypothesize Adenitire's adherence to one of two prominent conceptions of respect. The first is the minimal notion of recognition respect. 'To have recognition respect for someone as a person', Darwall states, 'is to give appropriate weight to the fact that he or she is a person by being willing to constrain one's behavior in ways required by that fact'. ${ }^{30}$ This seems congruent with Adenitire's insistence on respect for personal autonomy and liberty of conscience. Yet if we interpret Adenitire as drawing on duties of recognition respect, we encounter a problem. The problem is this: Brian Leiter has convincingly argued that recognition respect is coterminous with tolerance, in the sense that discharging our duties of recognition respect requires nothing more - or less - than tolerance. ${ }^{31}$ Adenitire, conversely, clearly distinguishes tolerance from respect.

On Leiter's argument, moreover, tolerance and recognition respect cannot support practices of exemptions. ${ }^{32}$ Adenitire, conversely, argues that respect mandates exemptions (for religious and non-religious conscience alike). ${ }^{33}$ One way to salvage Adenitire's argument for respect, is to interpret him as drawing on the thicker notion of appraisal respect. Appraisal respect, Darwall states, 'consists in an attitude of positive appraisal of [a] person' and is synonymous with esteem or high regard. ${ }^{34}$ The idea of appraisal respect might align with Adenitire's insistence on respect for individual well-being, which arguably entails more substantive commitments on the part of the state.

Crucially, appraisal respect - unlike recognition respect - is not coterminous with tolerance. ${ }^{35}$ Appraisal respect operates as a positive lens angled at acceptance. It is thus clearly distinct from the negative lens of tolerance, which is angled at disapproval. Interpreting Adenitire as drawing on the thicker notion of appraisal respect therefore solves one problem. Unfortunately, it also creates another: because appraisal respect is synonymous with esteem or high regard, the very same objections Adenitire invokes against tolerance can now be raised against appraisal respect. If judges are under a duty of neutrality that precludes

\footnotetext{
${ }^{29}$ Ibid at 287-291.

${ }^{30}$ Stephen L Darwall, 'Two Kinds of Respect' (1977) 88 Ethics 36, 45.

${ }^{31}$ Leiter (n 4) 72.

32 Ibid 103.

${ }^{33}$ Adenitire (n 6) 291-92.

${ }^{34}$ Darwall (n 30) 38.

${ }^{35}$ On Brian Leiter's account.
} 
them from disapproving of the content of conscientious objectors' beliefs, that same duty also precludes them from treating those beliefs with esteem or high regard. ${ }^{36}$ And if the state, qua collective entity, is incapable of displaying attitudes of disapproval, it is equally incapable of displaying attitudes of esteem.

It seems to me that there are at least two ways out of the paradox we seem to have ended up in. ${ }^{37}$ The first is to rely on the (contested) belief-conduct distinction to argue that, although lawmakers and judges should be neutral towards the content of a conscientious objector's beliefs, they are under no such duty in evaluating the consequences that follow when those beliefs are put into practice. This argument aligns with Adenitire's account: 'the position here defended is that the state ought to be neutral in regards to the content of beliefs but cannot, and should not, be neutral when it comes to assessing the impact of the actions of a conscientious objector on vital public interests or on the rights of others' ${ }^{38}$ But if this is correct, then surely judges can tolerate religious practices (just not beliefs). ${ }^{39}$ And conscientious objection of course involves both belief and conduct: it is a belief of what religion or morality requires, which is put into practice by refusals to serve in the military, perform abortions, marry same-sex couples, etc. It is precisely at this moment, when belief is put into practice, that the question of tolerance - or its 'adversary' of appraisal respect arises. $^{40}$

The second way out of the seeming paradox is to treat conscientious objection as a special category. On this argument, tolerance may not be the appropriate lens to evaluate religious beliefs in general. But it is an appropriate lens through with to view the specific category of conscientious objections. A useful vehicle for this narrower argument is Bernhard Schlink's recent characterization of ' $[\mathrm{t}]$ he freedom to object for reasons of conscience' as 'differ[ing] from all other constitutionally granted freedoms'. ${ }^{41}$ Schlink argues, rather persuasively, that ' $[\mathrm{t}]$ he freedom to object for conscientious reasons is a right that can be enjoyed by some members of society, but not by all ... In other words, it is a privilege [and

\footnotetext{
36 Adenitire acknowledges as much when he writes that 'the state has no place in expressing negative (or positive) moral judgments about the content of conscientious objectors' beliefs'. See Adenitire (n 6) 282 (my emphasis).

${ }^{37}$ I focus on the challenge from neutrality here, as it is Adenitire's main objection against tolerance.

${ }^{38}$ Adenitire (n 6) 282.

39 Adenitire invokes an argument from futility as his back-up (ibid 284.). I do not engage with that prudential argument here.

40 Adenitire acknowledges that '[t]he state regularly takes a moral stance about the acts carried out in pursuant to a moral or religious belief'. See ibid 281.

41 Bernhard Schlink, 'Conscientious Objections' in Susanna Mancini and Michel Rosenfeld (eds), The Conscience Wars: Rethinking the Balance between Religion, Identity, and Equality (CUP 2018) 102.
} 
not a claim right]'. ${ }^{42}$ To Schlink, in addition, '[t]here is something rebellious and anarchic about the conscience, and if it is taken as the ultimate authority governing social behaviour, the legal order is jeopardized.' ${ }^{43}$ It should be clear how an account of conscientious objection as a specific category of belief, with the anarchic potential to jeopardize the legal order, would lend itself to the language of tolerance. ${ }^{44}$

I am agnostic on which of the two routes - or a possible third route ${ }^{45}$ - we follow out of the paradox. The important point is that once we are out, we have created room for an account that merges the different perspectives provided by the contrasting lenses of tolerance and (appraisal) respect. Providing such an account is precisely what I aim to do in the next section.

\section{Conscientious Objection through the Contrasting Lenses of Tolerance and Respect}

My account, situated between Nehushtan's and Adenitire's, draws on the idea that tolerance and appraisal respect operate as contrasting lenses. Both notions provide different prisms through which religious (and other) claims can be evaluated. Appraisal respect operates as a positive lens, angled at acceptance. Tolerance, conversely, operates as a negative lens, angled at disapproval. In other words, the lens of appraisal respect is more permissive than the lens of tolerance.

Through the permissive lens of respect, ${ }^{46}$ conscientious objection is viewed in a positive light, as a good to be accepted and protected in its own right. As a result, a presumption operates in favour of protection and against restriction. Through the restrictive lens of tolerance, by contrast, conscientious objection is regarded with suspicion and

\footnotetext{
42 Ibid 103.

${ }^{43}$ Ibid. This echoes familiar Supreme Court rulings on exemptions in the United States. See Reynolds $v$ United States, 98 US 145 (1878) at 166 ('Can a man excuse his practices to the contrary [of the law] because of his religious belief? To permit this would ... permit every citizen to become a law unto himself. Government could exist only in name under such circumstances.'); Employment Division v Smith, 494 US 872 (1990) at 888 ('Any society adopting such a system [that is, applying a 'compelling interest' test to all actions thought to be religiously commanded] would be courting anarchy').

${ }^{44}$ But if it is not clear, I refer the reader to some of my other work. See references omitted for review purposes.

${ }^{45}$ For instance by adopting Peter Jones's conceptualization of tolerance as a moral ideal among citizens that is upheld by the state, instead of a political practice the state itself engages in towards its 'subjects'. Peter Jones, 'Toleration, Religion and Accommodation' (2015) 23 European Journal of Philosophy 542.

${ }^{46}$ Henceforth all references to 'respect' are to 'appraisal respect'. For ease of reading, I have omitted the word 'appraisal' throughout.
} 
disapproval. As a result, the presumption now operates against protection and in favour of restriction. Actions emanating from claims of conscience can of course still be tolerated, but only in exceptional circumstances, when superseding reasons are sufficiently powerful to overcome the disapproval. ${ }^{47}$

Drawing on a variation of a well-known distinction made by NeJaime and Siegel, I suggest that the contrasting lenses of tolerance and respect can be mapped onto two distinct categories of conscientious objections: those that infringe the legal rights of others and those that do not. ${ }^{48}$ Because the former have the capacity to negatively impact on the enjoyment of legal rights by others, the law has cause to be apprehensive of these rights-infringing claims of conscience. The converse is true of other - standard - claims of conscience. The contrasting notions of tolerance and respect capture this distinction well, given that the former operates as a more restrictive lens whereas the latter is more permissive.

Let us first consider standard claims of conscience. Some claims of conscience may impact on the general or public interest, but have no direct impact on the legal rights of others. These claims coincide entirely with NeJaime's and Siegel's category of standard claims of conscience. The impact of such claims is, as NeJaime and Siegel explain, 'limited and borne by society as a whole'. ${ }^{49}$ Conscientious objections to military service and to paying taxes are cases in point. Conscientious objectors who refuse to serve in the military or pay taxes do not directly undermine the legal rights of their fellow citizens. ${ }^{50}$ Unlike conscientious objectors to abortion or same-sex marriage, they do not refuse to provide a service to persons who have a legal right to receive the service. ${ }^{51}$ Instead, conscientious objectors to military service and paying taxes oppose legal obligations that purport to benefit

\footnotetext{
${ }^{47}$ For an account of how the different lenses of respect and tolerance are utilized in constitutional doctrine, see reference omitted for review purposes.

48 This distinction is not equivalent to the familiar Millian distinction between self-regarding and otherregarding action, to the extent that both categories of conscientious objection - the rights-infringing and the non-rights-infringing - have an impact on others (neither is thus entirely self-regarding). The difference between both instead resides in how tangible that impact is in terms of harm caused to the legal rights of identified or identifiable others (as opposed to a diffuse harm to society at large). See the discussion in the text below. For criticism of the distinction between self-regarding and other-regarding action, see Rex Ahdar and Ian Leigh, Religious Freedom in the Liberal State (Oxford University Press 2013) 165-166.

${ }^{49}$ NeJaime and Siegel (n 1) 2015.

50 See also Emmanuelle Bribosia and Isabelle Rorive, 'Seeking to Square the Circle: A Sustainable Conscientious Objection in Reproductive Health Care' in Susanna Mancini and Michel Rosenfeld (eds), The Conscience Wars: Rethinking the Balance between Religion, Identity, and Equality (CUP 2018) 411.

${ }^{51}$ See also Kent Greenawalt, 'Religious Toleration and Claims of Conscience' (2012) 28 Journal of Law and Politics 91, 106 ('[when] there are conflicting claims of toleration, it becomes debatable whether tolerance favours exemption. This contrasts with the issue of a pacifist's objection to military service ... [which] does not reflect badly on any other individuals in the society').
} 
the public or general interest (eg national security or budgetary interests). ${ }^{52}$ Whatever 'impact' these conscientious objectors have on the interests of their fellow citizens is dispersed across a vast number of persons, none of whom suffer tangible harm. It would therefore be inapposite to characterize their claims of conscience as rights-infringing. ${ }^{53}$

On the account I propose, such standard claims of conscience should be viewed through the more permissive lens of respect, precisely because they lack rights-infringing qualities. This does not, however, imply that these claims should always be protected. Respect, even qua esteem or high regard, is not limitless. But because respect is angled towards acceptance, exemptions should only be withheld in exceptional circumstances. For instance, the state's interest in maintaining operability of tax systems arguably justifies rejecting exemptions for conscientious objectors to paying taxes. ${ }^{54}$ There are two reasons for this. First, unlike for other claims of conscience, it is difficult to envisage alternative duties that might be imposed on conscientious objectors who refuse to pay taxes. ${ }^{55}$ Second, broad acceptance of conscientious objection to paying taxes would undermine the tax system as a whole, given the myriad ways in which taxes are used to fund activities potentially incompatible with a wide range of religious and moral beliefs (eg military spending, teaching evolution theory in public schools, vaccination campaigns, and wage payments to civil servants who marry same-sex couples). ${ }^{56}$

Turning to the second category, claims of conscience that do impinge on the legal rights of others, I submit that these should be regarded through the more restrictive lens of tolerance. ${ }^{57}$ Rights-infringing claims share features with, but are also distinct from NeJaime's and Siegel's complicity-based claims of conscience, which they define as 'religious objections to being made complicit in the assertedly sinful conduct of others' ${ }^{58}$ NeJaime and

\footnotetext{
52 See Chan Hiang Leng Colin and Others v Public Prosecutor [1994] SGHC 207 (HC; Singapore); United States v Lee, 455 US 252 (1982).

${ }^{53}$ See also Judith Jarvis Thomson, The Realm of Rights (Harvard University Press 1992) (arguing, under her 'High Threshold Thesis', that a person's claim cannot be justifiably overridden when the distribution of good arising from the infringement of the claim takes the form of tiny increments to a large amount of people).

${ }^{54}$ Beyond this point in the article, I no longer discuss conscientious objection to paying taxes, as I know of no jurisdiction that grants religious exemptions to paying general taxes (as opposed to, for instance, social security contributions).

55 This is different in other situations, such as conscientious objections to paying social security contributions. See Lee (n 52).

56 Ibid 260 ('[a] tax system could not function if denominations were allowed to challenge the tax system because tax payments were spent in a manner that violates their religious belief.').

${ }^{57}$ See also Greenawalt (n 51) 110 (describing exemptions for civil servants who object to registering same-sex marriages as a form of religious toleration).

${ }^{58}$ NeJaime and Siegel (n 1) 2519.
} 
Siegel recognize that these are 'bona fide faith claims', but nevertheless 'call for special scrutiny of these claims because of their distinctive capacity to harm other citizens' ${ }^{59}$

Complicity-based claims of conscience, as understood by NeJaime and Siegel, have an internal and an external dimension. ${ }^{60}$ Yet only the latter is arguably a relevant distinguishing feature in constructing different categories of conscientious objections. The irrelevant ${ }^{61}$ internal dimension refers to the nature of the objection. NeJaime and Siegel assume that their complicity-based claims of conscience are per definition other-regarding, in the sense that the religious person objects to complicity in the sinful conduct of others. ${ }^{62}$ Yet, as Douglas Laycock points out, this assumption is problematic in that it does not necessarily correspond to religious objectors' actual motivations. ${ }^{63}$ While some objectors may indeed be motivated to avoid complicity in the sinful conduct of third parties, for instance if they were to provide services for a same-sex marriages, others believe that they would themselves be committing a sin by providing these services.

What is more, as Laycock rightly observes, the idea of complicity is 'not doing any analytic work' in NeJaime's and Siegel's account. ${ }^{64}$ Indeed, what preoccupies NeJaime and Siegel first and foremost is the external dimension of the relevant claims; that is, their capacity to cause material and dignitary harms to others. ${ }^{65}$ Direct impact on the legal rights of others is also the only aspect I am concerned with, when it comes to categorizing these claims of conscience. As such, rights-infringing claims of conscience, as I employ this category, share the external dimension of NeJaime's and Siegel's complicity-based claims of conscience, but not its internal dimension. ${ }^{66}$

\footnotetext{
${ }^{59}$ Douglas NeJaime and Reva Siegel, 'Conscience Wars in Transnational Perspective: Religious Liberty, ThirdParty Harm, and Pluralism' in Susanna Mancini and Michel Rosenfeld (eds), The Conscience Wars: Rethinking the Balance between Religion, Identity, and Equality (CUP 2018)190.

${ }^{60}$ NeJaime and Siegel further argue that 'complicity claims can provide an avenue to extend, rather than settle, conflict about social norms in democratic contest'. See NeJaime and Siegel (n 1) 2520. This, however, speaks to political mobilisation around complicity-based claims of conscience and is not a conceptual dimension of this category of claims as such.

${ }^{61}$ Douglas Laycock, 'Religious Liberty for Politically Active Minority Groups: A Response to Nejaime and Siegel' (2016) 125 Yale LJ Forum 369, 382, <www.yalelawjournal.org/forum/religious-liberty-for-politicallyactive-minority-groups> accessed 19 January 2019.

${ }^{62}$ NeJaime and Siegel (n 1) 2519.

${ }^{63}$ Laycock (n 61) 382 and 386.

${ }^{64}$ Ibid 382. See also Marc O DeGirolami, 'Free Exercise by Moonlight' (2016) 53 San Diego L Rev 105, 137 139. NeJaime and Siegel appear to acknowledge as much when they write that the 'difference in the structure of [distinct] religious exemption claims is relevant-not to the claim's sincerity or religious significance, but instead to the claim's potential to inflict harms on specific third parties'. See NeJaime and Siegel (n 1) 2524. 65 Ibid 2527.

66 This has immediate consequences for how claims of conscience are classified. In their most recent account, NeJaime and Siegel exclude conscientious objections by doctors against performing abortions and by registrars
} 
In terms of consequences, however, NeJaime's and Siegel's argument that the law has cause to be suspicious of complicity-based claims of conscience applies equally forcefully to rights-infringing claims of conscience. I would go even further than that. When persons invoke their conscience to refuse to serve persons who have a legal right to receive the service, there is cause for more than suspicion. There is principled cause for disapproval. This does not imply that rights-infringing claims of conscience should always be rejected. Lawmakers and courts could opt to tolerate actions emanating from these claims, despite disapproval thereof.

Conscientious objection to abortion is an instructive example. Granting exemptions to doctors who conscientiously refuse to perform abortions strikes me as a defensible act of tolerance. Doctors' refusal to provide healthcare services to which women are legally entitled should elicit our disapproval. But there are good reasons, both normative and pragmatic, to nevertheless tolerate their claims of conscience. ${ }^{67}$ A good normative reason is empathy-based, to the extent that doctors would - in their eyes - be committing murder if forced to perform abortions. ${ }^{68}$ In that sense, inserting conscience clauses in abortion legislation recognizes the difficult moral dilemma in which religious doctors (may) find themselves.

A complementary pragmatic reason focuses on the alternative to tolerance: coercing doctors to perform abortions. ${ }^{69}$ On the pragmatic argument, the safety of surgical abortions may be in jeopardy if doctors are forced to proceed with what they consider murder. Presumably, doctors who oppose abortion would find it difficult to complete surgical abortion procedures under threat of coercion. In exceptional circumstances, that is in urgent cases where no willing doctor is available, we may still force objecting doctors to comply

\footnotetext{
against registering same-sex marriages from their category of complicity-based claims of conscience, since both instances entail direct participation in the objected-to-conduct and not 'mere' complicity (internal dimension). See NeJaime and Siegel (n 59) 201-202. The same objections do qualify, however, as rights-infringing claims of conscience on the account I propose in this article, since they have a direct impact on the enjoyment of legal rights by others (external dimension only).

67 Contra Bribosia and Rorive (n 50) 396 ('there are strong legal and principled arguments for refusing to accommodate conscientious claims in the field of reproductive health').

${ }^{68}$ See Lauren R Fink and others, "The Fetus Is My Patient, Too": Attitudes Toward Abortion and Referral Among Physician Conscientious Objectors in Bogotá, Colombia' (2016) 42 International Perspectives on Sexual \& Reproductive Health 71, 77 (reporting on interviews with conscientious objectors, in which several interviewees characterize abortion as murder).

${ }^{69}$ Referral duties are generally part of the tolerance solution, as a precondition to enjoyment of an exemption. In that sense, the alternative to tolerance entails coercion (and not referral).
} 
with their medical duties. But in non-exceptional cases, and from a pragmatic perspective, tolerating claims of conscience could serve to guarantee the safety of abortion procedures. ${ }^{70}$

Contrary to conscientious objection by doctors to abortion, I posit, conscientious objection to same-sex marriage should often not be tolerated. In the wake of same-sex marriage legislation, one category of conscience claims tends to be bitterly debated: objections by civil servants to the registration ${ }^{71}$ of same-sex marriages. ${ }^{72}$ Many scholars firmly reject the notion that civil servants can be exempt from registering same-sex marriages. Exemptions, they argue, cause same-sex couples material, ${ }^{73}$ psychological $^{74}$ and/or dignitary harm. ${ }^{75}$ Proponents of exemptions have countered that exemptions need not cause same-sex couples any harm, material or otherwise. ${ }^{76}$ They argue, among others, that practical systems can be implemented under which same-sex couples never even find out that a specific civil servant objects to registering their marriage. ${ }^{77}$ Such invisible administrative systems aim to distribute couples - heterosexual and same-sex alike - to civil servants who

\footnotetext{
70 This is also why extending medical abortions and minimizing surgical abortions could be a good practical response to widespread conscientious objections to abortion (given that doctors, gynaecologists and the like would no longer actively 'cause' the 'killing').

${ }^{71}$ I only address objections to 'registration' and not 'celebration' of marriages, as the argument in the text is intended for situations - and jurisdictions - in which civil servants act as the mouth and hands of the state (see below). This is clearly true of civil servants who are mandated to perform strictly administrative acts of registration. Where to draw the line between registration and celebration is an important, but difficult question that may need to be assessed on a case-by-case (or jurisdiction-by-jurisdiction) basis. In section 3, I discuss the example of South Africa. There, marriage officers 'solemnize' same-sex unions under the Civil Union Act 2006. In doing so, they are given these instructions: 'the marriage officer must put the following questions to each of the parties separately ... "Do you, A.B., declare that as far as you know there is no lawful impediment to your proposed marriage/civil partnership with C.D. here present. and that you call all here present to witness that you take C.D. as your lawful spouse/civil partner?" and thereupon the parties must give each other the right hand and the marriage officer concerned must declare the marriage or civil partnership, as the case may be, solemnised in the following words: "I declare that A.B. and C.D. here present have been lawfully joined in a marriage/civil partnership." See Civil Union Act 2006, section 11(2). Since the marriage officer is bound to follow these exact words and in doing so acts as the mouth of the state, which recognizes the marriage as lawful, I consider this to be more an act of 'registration' than 'celebration'. I do not intend to put forth an argument, in this article, for the more difficult case of 'celebration' by civil servants, mostly because unpacking what 'celebration' means would require detailed discussion of different concrete examples. But I should note that this situation is not necessarily analogous to that of a doctor who refuses to perform an abortion (rather, it seems to me that the analogous situation would be that of obliging religious ministers to celebrate same-sex marriages, which for obvious reasons does not occur).

${ }^{72}$ In this article, I focus on this subset of conscientious objection to same-sex marriage and ignore others, such as refusals to bake wedding cakes or make photographs for same-sex marriages.

${ }^{73}$ Robert Wintemute, 'Accommodating Religious Beliefs: Harm, Clothing or Symbols, and Refusals to Serve Others' (2014) 77 MLR 223.

${ }^{74}$ Michael Kent Curtis, 'A Unique Religious Exemption From Antidiscrimination Laws in the Case of Gays? Putting the Call for Exemptions for Those Who Discriminate Against Married or Marrying Gays in Context' (2012) 47 Wake Forest Law Review 173, 186 and 197.

${ }^{75}$ NeJaime and Siegel (n 1).

${ }^{76}$ Robin Fretwell Wilson, 'The Calculus of Accommodation: Contraception, Abortion, Same-Sex Marriage, and Other Clashes Between Religion and the State' (2012) 53 BCL Rev 1417, 1487 and 1506; Greenawalt (n 50) $116-17$.

${ }^{77}$ Wilson (n 76) 1506.
} 
are willing to register their marriage. ${ }^{78}$ Yet these systems operate only to enable objections to same-sex marriages, not objections to other marriages (eg marriage after divorce). At this juncture, opponents of exemptions often invoke the analogy to interracial marriage. ${ }^{79}$ If we do not tolerate civil servants who object to interracial marriages, they ask, why should we tolerate those who refuse to register same-sex marriages? ${ }^{80}$

Although the analogy to interracial marriage is imperfect, ${ }^{81}$ the question is valid to the extent that it illuminates the nature of the harm involved. Ever since John Stuart Mill wrote On Liberty, liberalism has established a strong link between tolerance and harm, in the sense that the limits of tolerance are drawn by the harm principle. ${ }^{82}$ The breadth of these limits is determined by how one interprets harm. I posit that conscientious objections by civil servants to registering same-sex marriages cannot be tolerated, because these objections - when put into practice - cause persons in a same-sex couple expressive harm. ${ }^{83}$ Expressive harm is the harm a person suffers 'when she is treated [by the State] according to principles that express negative or inappropriate attitudes toward her' ${ }^{84}$ Some of the historically most prominent examples are of caste or racial segregation, once prevalent in India, South Africa and the United States. Racial segregation causes expressive harm, because it 'sends the message that

\footnotetext{
78 Ibid.

${ }^{79}$ Curtis (n 74) 177 and 184; Bruce MacDougall, 'Refusing to Officiate at Same-Sex Civil Marriages' (2006) 69 Saskatchewan Law Review 351, 357.

${ }^{80}$ It goes without saying that this is a controversial question. One prominent response is that the analogy misses the point entirely. This response relies on the New Natural Law argument that same-sex marriage is not wrongful marriage, but not marriage at all. John Finnis, for instance, conceives of marriage as a basic human good with particular purposes (friendship and procreation), which precludes it from being open to persons of the same sex. See John Finnis, 'Marriage: A Basic and Exigent Good' in John Finnis, Human Rights and Common Good: Collected Essays Volume III (Oxford University Press 2011) 317-333. I find this argument unconvincing, among other reasons because it a) seemingly denies marriage to persons of different sex who marry at an advanced age in life (when they can no longer aim to reproduce); b) underestimates the capacity of relationships outside of marriage to fulfil precisely the same purposes; c) ignores technological and other evolutions (eg increased use of adoption) that enable couples to have children without (marital) sex; and d) caricaturizes and misrepresents the nature of love and sexual relations among persons of the same sex.

${ }^{81}$ Curtis (n 74) 185.

82 John Stuart Mill, On Liberty, Utilitarianism, and Other Essays (first published 1859, OUP 2015); Joseph Raz, 'Autonomy, Toleration, and the Harm Principle' in Susan Mendus (ed), Justifying Toleration: Conceptual and Historical Perspectives (CUP 1988).

${ }^{83}$ Contra DeGirolami (n 64) 142 (arguing that there is emotional harm on both sides; that is, if objectors are denied an exemption because their moral views are not tolerated, they too suffer dignitary harm). Although this counterargument carries some force, I am not convinced that both harms are equivalent. Nevertheless, the counterargument does provide, along with concerns about the slippery notion of harm if expanded beyond material harm, good reasons to restrict the reach of the argument from expressive harm. I explain the limits of that argument, as I conceive of it, in the text (see text to $n$ 88-92).

${ }^{84}$ Elizabeth S Anderson and Richard H Pildes, 'Expressive Theories of Law: A General Restatement' (2000) 148 U Pa LR 1503, 1527.
} 
blacks are untouchable, a kind of social pollutant from which "pure" whites must be protected'. ${ }^{85}$

Although, as already conceded, the analogy to same-sex marriage is imperfect, it strikes me as broadly compelling. ${ }^{86}$ When civil servants refuse to register same-sex marriages, they cause partners in a same-sex couple expressive harm, just as when they would refuse to marry partners in an interracial relationship. Objecting civil servants furthermore act as state agents, and their duties of registration are state duties. ${ }^{87}$ For all intents and purposes, they act as the mouth and hands of the state when they register marriages.

The last point is crucial, as it pre-empts a familiar worry about expressive harm: its elusive and indeterminate character. ${ }^{88}$ The worry is commonly stated in the following form: if the preoccupation of expressive harm is with preventing offense to feelings, could not most conscientious objections be construed in terms of expressive harm? And would this not drastically circumscribe the scope for exemptions for conscientious objectors $?^{89}$ These are legitimate concerns. Yet, expressive harm - as I conceive of it - is not coterminous with offense to feelings. Instead, it refers to harm that meets two requirements. First, it is caused by the state and/or its agents. Second, it originates in actions by the state and/or its agents by which a segment of the population is treated as second-class citizens. Concretely, this means that doctors who refuse to perform abortions do not cause women expressive harm. ${ }^{90}$ Unlike civil servants, doctors do not act as the mouth and hands of the state. ${ }^{91}$ Furthermore, the health services they deliver are distinct from legal status services, the recognition of which are uniquely in the power of the state. Contrary to civil servants acting for the state, then, doctors do not have the power to cast a segment of the population into a status of social subordination..$^{92}$

\footnotetext{
85 Ibid.

${ }^{86}$ Contra Wilson (n 76) 1476; Greenawalt (n 51) 113.

${ }^{87}$ MacDougall and others (n 3) 138.

${ }^{88}$ See, for instance, Simon Blackburn, 'Group Minds and Expressive Harm’ (2001) 60 Maryland L Rev 467, 489 (referencing 'the mongrel doctrine of expressive harm').

${ }^{89}$ See, for instance, DeGirolami (n 64) 134-35.

${ }^{90}$ It also means that bakers who refuse to make wedding cakes for same-sex marriages do not cause expressive harm. They do, however, still cause material harm.

91 This may limit the argument to those jurisdictions in which this can sensibly be said of civil servants, although I do not think it should.

${ }^{92}$ Cf. Nancy Fraser, 'Rethinking Recognition' (2000) 3 New Left Rev 107, 113-14.
} 


\section{Comparative Complication}

In the previous section I proposed a normative-conceptual argument, on which different claims of conscience are evaluated through the contrasting lenses of tolerance and respect. In this section, I aim to complicate that argument through comparative analysis. I show that different constitutional democracies have adopted diverging legal responses to conscientious objection to military service, abortion and same-sex marriage, respectively. For each category of conscientious objection, I contrast a pair of constitutional democracies. In each pair, one constitutional democracy favours the approach I have proposed in Section 2, while the other has adopted the opposite solution.

The comparative discussion deliberately eschews the 'usual suspects' ${ }^{93}$ of the field. We already know enough about how courts and lawmakers in the United States, Canada and the United Kingdom have responded to claims of conscience. Instead, I discuss some less familiar jurisdictions. For conscientious objection to military service, I compare Singapore to the Republic of Korea. For conscientious objection to abortion, I compare Colombia to Sweden. Here, I also introduce Italy (admittedly more of a 'usual suspect') as a useful juxtaposition. For conscientious objection to same-sex marriage, finally, I compare the Netherlands to South Africa. My primary aim in this section is to tease out, from the comparative analysis, practical factors that may complement or even supersede the normative argument of Section 2. I briefly discuss these practical factors, along with the baseline they provide, in the conclusion.

\section{A. Conscientious objection to military service: Singapore and the Republic of} Korea

In many constitutional democracies, military service is no longer compulsory. As a result, conflicts between individual conscience and national security no longer arise. Even where military service remains mandatory, most constitutional democracies have catered to conscientious objectors by introducing alternative civilian service. ${ }^{94}$ Singapore, however, deviates from this global trend. In Singapore, a state that has been described as 'quasi-

\footnotetext{
${ }^{93}$ Hirschl (n 19) 4.

${ }^{94}$ In Europe, see Bayatyan v Armenia ECHR 2011-IV 1 (and the comparative discussion therein).
} 
secular' ${ }^{95}$ and pragmatically secular, ${ }^{96}$ military service is compulsory for every person ${ }^{97}$ above the age of $18 .^{98}$ Singapore law provides for exemptions in limited circumstances, including 'exceptional hardship of the applicant or members of his household'. ${ }^{99}$ But there are no exemptions for conscientious objectors. Instead, conscientious objectors are guilty of criminal offences that carry prison sentences of up to three years. ${ }^{100}$

In direct contradiction to what I have proposed in Section 2, Singapore thus does not respect claims of conscience against serving in the military. It does not even tolerate such claims. Instead, Singapore law is intolerant of conscientious objection to military service. The clearest sign of this intolerance is the deregistration, in 1972, of the Singapore Congregation of Jehovah's Witnesses and concomitant ban on their Watch Tower publications. ${ }^{101}$ Objections by Jehovah's Witnesses to serving in the military were the immediate catalyst for the deregistration and ban: ${ }^{102}$

'[their] continued existence is prejudicial to public welfare and good order in Singapore. ... the sect claims a neutral position for its members in wartime. This has led to a number of Jehovah's Witnesses in the National Service to refuse to do any military duty. Some of them even refuse to wear uniforms. ${ }^{303}$

In 1994, the High Court of Singapore upheld the ban on Watch Tower publications. In the process, it confirmed that ' $\left[\mathrm{t}\right.$ ] here is no tradition of [conscientious objection] in Singapore'. ${ }^{104}$ The court stated that ' $[\mathrm{t}]$ he sovereignty, integrity and unity of Singapore are undoubtedly the paramount mandate of the Constitution'. ${ }^{105}$ As Jaclyn Neo explains, ${ }^{106}$ the court gave this

\footnotetext{
${ }^{95}$ Li-ann Thio, 'Taking Rights Seriously? Human Rights Law in Singapore' in Randall Perenboom and others (eds), Human Rights in Asia (Routledge 2006) 165. For discussion, see Jaclyn Neo, 'Secular Constitutionalism in Singapore: Between Equality and Hierarchy' (2016) 5 Oxford Journal of Law \& Religion 431.

${ }^{96}$ Eugene K B Tan, 'Keeping God in Place: The Management of Religion in Singapore', in Lai Ah Eng (ed), Religious Diversity in Singapore (ISEAS 2008) 66 (Tan describes it as pragmatic secularism, because it 'seeks to harness the powerful potential of religion [in, among others, inculcating good citizenship and encouraging industriousness] while ensuring that the secular always takes precedence over the sacred').

${ }^{97}$ In practice this is interpreted to refer only to men.

${ }^{98}$ Enlistment Act 1970, section 10(1).

${ }^{99}$ Ibid, section 29; Enlistment Regulations 1970, section 23.

${ }^{100}$ Enlistment Act 1970, section 33; Singapore Armed Forces Act 1972, section 17(1).

${ }^{101}$ This was followed by persecution of Jehovah's Witnesses. See Li-ann Thio, 'Pragmatism and Realism Do Not Mean Abdication: A Critical and Empirical Inquiry into Singapore's Engagement with International Human Rights Law' (2004) 8 Singapore Yearbook of International Law 41, 77-8.

${ }^{102}$ Li-ann Thio, 'The Secular Trumps the Sacred: Constitutional Issues Arising from Colin Chan v Public Prosecutor', 16 Singapore Law Review (1995) 54.

103 Press statement by the Ministry of Home Affairs accompanying the deregistration, as cited in Chan Hiang Leng Colin (n 52).

${ }^{104}$ Chan Hiang Leng Colin (n 52). For a critique of the judgment, see Thio (n 86).

105 Chan Hiang Leng Colin (n 52).

${ }^{106}$ Neo (n 95) 442-43. See also Thio (n 95) 162.
} 
'paramount mandate' lexical priority over all other interests by proclaiming that 'anything, including religious beliefs and practices, which tend to run counter to these objectives must be restrained' ${ }^{107}$ The court acknowledged that dozens of men are court-martialled each year for refusing to serve in the military, but held that 'we have no alternative ... because they are violating the law'. ${ }^{108}$ 'In many Western European countries', the court concluded, 'they would count as conscientious objectors. But the idea of conscientious objection does not apply in Singapore.' ${ }^{109}$

In short, the Singapore High Court has ruled that conscientious objection to military service cannot be tolerated, because it runs counter to state sovereignty. ${ }^{110}$ The government of Singapore has consistently adopted the same position in the context of the UN Human Rights Council, making it abundantly clear that Singapore 'does not recognize the universal applicability of the right to conscientious objection to military service'. ${ }^{111}$ At the same time, Singapore has elevated national defence to the status of 'a fundamental sovereign right under international law' that trumps individual beliefs. ${ }^{112}$ As a result, '[w]here individual beliefs or actions run counter to [this] right, the right of a State to preserve and maintain national security must prevail ${ }^{113}$. The size and location of the country plays a central role in justifying this rigid stance:114 'for a small country like Singapore, compulsory military service is the only way to build up a credible national defence force.' ${ }^{115}$ Under this national security narrative, conscientious objectors cannot be tolerated because they threaten to undermine the system: 'allowing any individual ... on the basis of conscientious objection, to be excused from military service will fundamentally undermine the ... collective responsibility for national defence [and] compromise national values'. ${ }^{116}$

Singapore thus justifies its legal intolerance of conscientious objectors to military service with reference to a slippery slope argument. Although Jehovah's Witnesses are small

\footnotetext{
${ }^{107}$ Chan Hiang Leng Colin (n 52).

108 Ibid.

109 Ibid.

${ }^{110}$ Tan (n 96) 63.

${ }^{111}$ Note verbale from the Permanent Mission of the Republic of Singapore to the United Nations Office and other international organizations in Geneva addressed to the Office of the United Nations High Commissioner for Human Rights (4 June 2013) A/HRC/23/G/6 [hereafter 'Note verbale Singapore']; Statement by the Permanent Mission of Singapore during Agenda Item 3 of the 35th Session of the Human Rights Council (13 June 2017) available at <www.mfa.gov.sg/content/mfa/overseasmission/geneva/speeches_and_statementspermanent_mission_to_the_UN/2017/201706/20170613.html> accessed 17 August 2018.

112 Note verbale Singapore (n 111).

113 Ibid.

114 Thio (n 101) 57.

115 Ibid.

116 Ibid.
} 
in number, ${ }^{117}$ the government and courts assume that exempting them from military service will open the floodgates for other claims of conscience, ultimately undermining the collective system of compulsory military service. ${ }^{118}$ For decades, this is also how legislators and courts in South Korea reasoned in relation to conscientious objection to military service on the heavily militarized Korean peninsula. In June 2018, however, an important new judgment of the Constitutional Court of the Republic of Korea caused a wholesale shift in attitude towards conscientious objection in Korean law. To understand the ramifications of the new judgment, we must first examine what came before.

The Constitution of the Republic of Korea imposes upon '[a]ll citizens ... the duty of national defence'. ${ }^{119}$ The Military Service Act 2011 operationalizes this constitutional duty by proscribing that '[e]very masculine gender [sic] of the Republic of Korea shall faithfully perform military service'. ${ }^{120}$ Under the Act, those who evade enlistment 'shall be punished by imprisonment for not more than three years'. ${ }^{121}$ The Act does not provide for exemptions for conscientious objectors, a failing that must now be amended in light of the new Constitutional Court judgment. ${ }^{122}$ Prior to that judgment, every year several ${ }^{123}$ hundreds of conscientious objectors were sentenced to an average of 18 months imprisonment in South Korea. ${ }^{124}$

Initially, the Constitutional Court of the Republic of Korea upheld the constitutionality of the Military Service Act, in both 2004 and 2011. In both judgments, the Court put the interest in national security front and centre, very much like the Singapore High Court. The Korean Court described national security as an 'indispensable prerequisite for the existence of the nation [and] a basic prerequisite for the exercise of the freedom by all citizens' ${ }^{125}$ It considered conscientious objection to military service incompatible with preserving national security: ' $[\mathrm{t}]$ he freedom of conscience of Article 19 of the Constitution does not endow the individuals with the right to refuse the performance of the duty of

\footnotetext{
${ }^{117}$ Estimates speak of a few thousands (in a population of 5.8 million).

118 Thio (n 95) 166.

${ }^{119}$ Constitution of the Republic of Korea, Article 39.

${ }^{120}$ Military Service Act 2011, Article 3(1).

${ }^{121}$ Ibid, Article 88(1).

122 The Constitutional Court has given the legislature until 31 December 2019 to include alternative civilian service in the legal framework on military service.

${ }^{123}$ Estimates range from 600 to 900 persons per year. See Jeong v Korea, Communication no. 1642-1741/2007 (HRC, 24 March 2011), para 2.3; Ihntaek Hwang, 'Militarising National Security through Criminalisation of Conscientious Objectors to Conscription in South Korea' (2018) Critical Studies on Security 1, 2.

${ }^{124}$ Jeong (n 123), para 2.1; Hwang (n 123) 1.

${ }^{125}$ Conscientious Objection of Military Service Case 16-2(A) KCCR 141 (26 August 2004) 22-23.
} 
military service'. ${ }^{126}$ The Court further argued that the 'unique security situation' in South Korea precluded tolerance of conscientious objection to military service. ${ }^{127}$ This 'unique security situation' refers to the fact that 'our nation is the only divided nation in the world that is under the state of truce, and the South and the North are still in a hostile opposition state'. 128

Until recently, then, the Constitutional Court denied that freedom of conscience entails a 'right to refuse to perform legal obligations on the ground of conscience'. ${ }^{129}$ Instead, the Court only saw a 'right to request the state to take into account and protect the individual conscience if possible'. ${ }^{130}$ The last passage evokes familiar - and antiquated - notions of religious tolerance as legislative grace. ${ }^{131}$ On the early modern conception of tolerance, acts of tolerance were privileges granted by the powerful (in early modern times, the European monarchs) to persecuted minorities. The Constitutional Court of Korea used to deploy an analogous understanding of tolerance by emphasizing that the 'right to request' exemptions could only be protected 'within the scope that the national community may tolerate the conscience'. ${ }^{132}$ Crucially, this tolerance did not extend to exemptions for conscientious objectors.

In June 2018, however, all this changed. ${ }^{133}$ In a landmark judgment, the Constitutional Court ruled that the absence of alternative service options in the Korean legal framework on military service violates the Constitution. ${ }^{134}$ For our purposes, the new judgment is especially significant in that it rejects some of the central arguments in Singapore. As explained, legal intolerance of conscientious objection to military service in Singapore is founded on a slippery slope argument. This argument used to have significant traction in South Korea as

\footnotetext{
${ }^{126}$ Ibid at 24.

${ }^{127}$ Ibid at 28. See also Conscientious Objector Case (Military Service Act) 23-2(A) KCCR 174 (Constitutional Court of the Republic of Korea, 30 August 2011) at 281-82 (official English summary of judgment; no full translation available). See further Jeong (n 123), paras 4.2 and 4.3 (in which the Korean government explained how, in its view, the security situation in South Korea is different from that in Germany and Taiwan, two countries that have introduced alternative civilian service).

${ }^{128}$ Conscientious Objection of Military Service Case (n 125) 28.

${ }^{129}$ Ibid at 24.

130 Ibid.

${ }^{131}$ See Michael W McConnell, The Origins and Historical Understanding of Free Exercise of Religion, (1990) 103 Harv Law Rev 1409, 1443; Nussbaum (n 4) 90 (both referencing James Madison).

${ }^{132}$ Conscientious Objection of Military Service Case (n 125) 29.

${ }^{133}$ The change could be due - at least in part - to evolutions in public opinion. Polls indicate that societal disapproval of conscientious objection to military service in South Korea has dropped from 89.9\% in 2005 to $52.1 \%$ in 2016. Hwang (n 123) 13.

${ }^{134}$ Case on Conscientious Objectors 2011 Hun-Ba 379 (28 June 2018). As of writing, no official translation of the full judgment is available. The discussion in the text is based on the official English summary of the judgment.
} 
well. But no longer. The Constitutional Court now recognizes that the number of conscientious objectors in South Korea is simply not large enough to have a concrete impact on the national defence power of the country. The Court further holds that there are ways to ensure that alternative civilian service is at least equivalent to military service (eg by controlling its difficulty and duration), thereby avoiding or minimizing the risk of abuse by insincere objectors. ${ }^{135}$

Two factors - availability of sufficiently 'tough' alternative duties and low numbers of objectors - thus inform the Korean Court's new conclusion that rejecting alternative civilian service cannot be justified with reference to the 'unique security situation' on the Korean peninsula. As we will see in the comparative discussion of other instances of conscientious objection, both factors - availability of alternative duties and frequency of objections - return time and again. In the conclusion to this article, I will suggest that the interaction between both factors is key to identifying a practical baseline for legal responses to claims of conscience.

\section{B. Conscientious objection to abortion: Colombia, Sweden and Italy}

In 2006, the Constitutional Court of Colombia transformed the abortion landscape in Colombia by introducing a legal right to abortion in certain circumstances (including risks to life or health of the pregnant woman, and pregnancy resulting from rape). ${ }^{136}$ Yet, despite this constitutional transformation, '[e]stimates suggest that in 2008, the vast majority of abortions were [still] performed illegally and unsafely'. ${ }^{137}$ Widespread conscientious objections to abortion, claimed by individuals and institutions alike, remained a major practical obstacle for effective access to legal abortion in Colombia. ${ }^{138}$ The Constitutional Court therefore had ample cause to tackle conscientious objections to abortion.

The Constitutional Court of Colombia recognizes that conscientious objection is a genuine right that can be claimed against the state - not a mere privilege to be requested from

\footnotetext{
135 The Court also points out that this is a better way to accomplish public interests than 'just imprisoning the objectors'. See ibid.

136 Sentencia C-355/06.

${ }^{137}$ Fink and others (n 68) 71.

138 Sentencia T-388/09 at 17.
} 
the state. ${ }^{139}$ As a result, the state has to justify interferences with the right to conscientious objection. ${ }^{140}$ At the same time, the state also has to guarantee respect for the rights of others, 'to obtain at least a minimum of ... social cohesion under the respect for pluralism commanded expressly by the Constitution [in its Article 1]' ${ }^{141}$ Conscientious objection thus raises, in the eyes of Colombia's Constitutional Court, complex questions of balancing social cohesion with respect for diversity. Finding the right balance is particularly pressing, the Court has held, when 'the externalization of one's own moral convictions with the intention of evading fulfilment of a legal obligation interferes with the exercise by others of their rights'. ${ }^{142}$ In line with the argument proposed in Section 2, the Colombian Court thus explicitly distinguishes rights-infringing conscientious objections from standard conscientious objections. In relation to the latter, the Court has found, 'one does not perceive any reason to impede the exercise of the conscientious objection' ${ }^{143}$

The Constitutional Court has discussed a range of conscientious objections to abortion, ruling in respect of each whether they can be tolerated or not. ${ }^{144}$ As in the case of conscientious objection to military service, availability of alternative duties and frequency of objections are key factors in the constitutional analysis. According to the Colombian Court, doctors can legitimately exercise claims of conscience, but only when another doctor is guaranteed to perform the abortion and the woman's rights are effectively preserved through a referral process (that is, the referral process should not result in additional obstacles for access to abortion). ${ }^{145}$ At the same time, the Court has also ruled that when only one doctor is available to perform an abortion - eg because the state and health institution have failed to secure availability of sufficient non-objecting doctors - it is 'completely legitimate' to force that doctor to perform an abortion against her conscience. ${ }^{146}$ Thus, when the practical factors of alternative duties and frequency of objections are misaligned, conscientious objection to abortion cannot be tolerated.

\footnotetext{
139 Ibid at 48 .

${ }^{140}$ Ibid.

${ }^{141}$ Ibid at 47 (own translation).

${ }^{142}$ Ibid at 49 (own translation).

${ }^{143}$ Ibid at 50 (own translation).

${ }^{144}$ Although the Constitutional Court interprets the right to conscientious objection to abortion restrictively, exploratory qualitative research indicates that 'these [court] regulations are not being implemented and that conscientious objection is being used [in practice] for denial of care'. See Fink and others (n 68) 78.

145 Sentencia T-388/09 at 51-52.

146 Ibid at 51.
} 
The Constitutional Court is further adamant that the right to conscientious objection can only be legitimately exercised by medical staff directly involved in the termination procedure. ${ }^{147}$ The Court has listed a whole range of actors who, by contrast, cannot claim an exemption for reasons of conscience. These include administrative staff, those who prepare the intervention and those who assist in post-intervention care. ${ }^{148}$ In relation to these categories of persons, the Court concludes that their acts 'do not hold any relation with the nature of conscientious objection'. ${ }^{149}$

The Constitutional Court has further underscored that the right to conscientious objection is limited to individual persons and cannot be exercised by health institutions and other collective entities, since the latter do not have a conscience. ${ }^{150}$ The Court has noted that 'there cannot exist clinics, hospitals, healthcare centres [etc] that invoke conscientious objections to performing abortions' ${ }^{151}$ This is particularly relevant in light of the reality that health institutions often invoke reasons of conscience to erect significant practical obstacles to access to abortion in Colombia. ${ }^{152}$

The Constitutional Court has finally clarified that, although conscientious objection is a right, it cannot be invoked by individuals who exercise public authority: '[t]hose who hold such functions cannot rely on reasons of conscience to refuse to fulfil their constitutional and legal obligations ... under Articles 2 and 6 of the Constitution'. ${ }^{153}$ In respect of judges, in particular, the Court has held that voluntary acceptance of their role as judicial authority entails a commitment to strict upholding of the law. ${ }^{154}$ '[T] heir convictions', the Court has ruled, 'do not release them from their responsibility to administer justice based uniquely and exclusively in the law'. ${ }^{155}$

In Colombian constitutional law, then, conscientious objection to abortion is tolerated, but only for a limited group of individuals and only in narrowly tailored circumstances. Under Swedish law, by contrast, conscientious objection to abortion is not tolerated at all.

\footnotetext{
${ }^{147}$ Ibid at 53.

${ }^{148}$ Ibid. The Court specifically lists - among others - reception staff, cleaning personnel, medical staff who conduct preliminary tests and psychologists.

${ }^{149}$ Ibid.

${ }^{150}$ Ibid at 54.

${ }^{151}$ Ibid (citing the C-355/06 judgment; own translation).

152 Ibid at 17.

${ }^{153}$ Ibid (own translation). Article 2 of the Constitution of Colombia is particularly pertinent. It states, in relevant part, that ' $[\mathrm{t}] \mathrm{he}$ authorities of the Republic are established to protect the rights and freedoms of all persons residing in Colombia' (own translation).

154 Ibid at 56.

${ }^{155}$ Ibid at 57 (own translation).
} 
Sweden is one of the few constitutional democracies that do not even exempt doctors who refuse to perform abortions for reasons of conscience. The deliberate decision not to insert a conscience clause in Swedish abortion legislation was motivated by 'strong convictions about the importance of public service provision and related civic duties, and ideals about rule of law, equality and non-discrimination'. ${ }^{156}$ In the absence of a statutory conscience clause, accommodation of conscientious objectors is left to the discretion of hospitals and other health institutions. ${ }^{157}$ Although accommodation does occur in practice, it is 'legally optional for the employer, and ... constrained by the obligation to secure provision and quality of services' ${ }^{158}$

Sweden also exemplifies the process - indicated earlier in this article - by which antiabortion movements have switched tacks from attacking liberal abortion legislation itself to critiquing failures to cater to the right to conscientious objection of medical staff. ${ }^{159}$ Recently, these efforts have crystallized in the high-profile court case of midwife Ellinor Grimmark. ${ }^{160}$ Grimmark was refused employment at three different health institutions for her objection to performing abortion services, based on her 'conscientious convictions' about 'the sanctity of all human life'. ${ }^{161}$ When Grimmark brought her case to the Swedish courts, the Alliance Defending Freedom International - an offshoot of the US conservative religious organization - filed an expert brief in her support. ${ }^{162}$ The Swedish courts, however, rejected Grimmark's claim of religious discrimination. ${ }^{163}$ She now works across the border in Norway, where abortion legislation does include a conscience clause. ${ }^{164}$

In a final bid to challenge the absence of a legal right to conscientious objection to abortion in Sweden, Grimmark - along with Linda Steen, another Swedish midwife -

\footnotetext{
156 Christian Munthe, 'Conscientious Refusal in Healthcare: The Swedish Solution' (2017) 43 Journal of Medical Ethics 257, 257.

157 Federation of Catholic Families in Europe (FAFCE) v Sweden Complaint no 99/2013 (ECSR, 17 March 2015), para 55 (submissions of the Swedish government).

158 Ibid (emphases removed from original).

${ }^{159}$ Heli Askola, 'Dropping the Ball or Holding the Line? Challenges to Abortion Laws in the Nordic Countries' (2018) 66 Women's Studies International Forum 25, 26.

160 At the same time, the small Christian Democrat Party and the anti-immigration Sweden Democrats Party have - in an unusual alliance - submitted bills to parliament to introduce a legal right to conscientious objection for medical staff. See ibid.

161 ADF International, 'Swedish midwife turns to European Court of Human Rights' (14 June 2017) $<$ https://adfinternational.org/news/swedish-midwife-turns-to-human-rights-court> accessed 17 August 2018.

162 Ibid.

163 Askola (n 159) 26. For comments, see Melisa Vazquez, 'Abortion Inside Swedish Democracy: the case of Ellinor Grimmark' (Diritti Comparati, 22 June 2015) <www.diritticomparati.it/abortion-inside-swedishdemocracy-the-case-of-ellinor-grimmark/\#sthash.0wmjJ8Qh.dpuf $>$ accessed 17 August 2018.

${ }^{164}$ ADF International (n 161).
} 
recently filed an application at the European Court of Human Rights (ECtHR). ${ }^{165}$ The ECtHR is thus set to become the second European body to examine legal intolerance of conscientious objection to abortion in Sweden. Its 'sister-body', the European Committee of Social Rights (ECSR), has already rejected claims that Swedish law violates the right to health in Article 11 of the European Social Charter (ESC). ${ }^{166}$ Under the ESC, however, the claimants were forced to argue - counter-intuitively - that the right to health requires accommodation of conscientious objection to abortion. Unsurprisingly, this contrived legal argument did not stick. ${ }^{167}$ At the ECtHR, however, Grimmark and Steen can invoke their freedom of conscience and religion (rights protected under Article 9 of the European Convention on Human Rights, but not in the ESC).

Grimmark's and Steen's case is the first in which the ECtHR is called upon to rule whether the complete absence of a legal exemption for conscientious objectors to abortion passes European muster. ${ }^{168}$ This is a thorny question, given that most European states do cater for a legal right to conscientious objection to abortion for medical staff. The European consensus, which tends to inform the Court's rulings on sensitive moral issues, ${ }^{169}$ thus seems to point towards a different solution than Sweden's. The ECtHR may moreover have to choose between - or attempt to reconcile - diverging strands of its case law in deciding the case. On the one hand, there is a strand of case law in a couple of Polish cases, in which the Court has indicated that 'States are obliged to organize the health services system in such a way as to ensure that an effective exercise of the freedom of conscience of health professionals ... does not prevent patients from obtaining access to [abortion] services'. ${ }^{170}$ The question in Grimmark is, does the opposite also hold? Are European states obliged to organize their health system in such a way as to ensure that access to abortion is compatible with the exercise of conscientious objection by medical staff? Here, a second strand of case

\footnotetext{
165 Ibid.

${ }^{166}$ FAFCE (n 157).

${ }^{167}$ Ibid at 70 ('Article 11 of the Charter is primarily concerned with ... guaranteeing access to adequate health care, and this means in cases of maternity that the primary beneficiaries are the pregnant women').

168 As of writing, no further information was available on the status of the application at the ECtHR (the application was filed in June 2017). There are several possibilities. The most likely is that the application is still being processed by the Court's Registry. An alternative possibility is that the application has already been declared inadmissible under the Single Judge procedure. Decisions made under this procedure are only communicated to applicants and/or their lawyers. They are not made public. This possibility seems less likely, however, as a Single Judge decision would imply that the application was held to be manifestly ill-founded (which seems implausible in the case of Grimmark and Steen, given that the Court has not decided analogous cases previously). A third, even less likely possibility, is that Sweden is negotiating a settlement with the applicants.

${ }^{169}$ But see A. B. and C. v Ireland ECHR 2010-VI 185.

${ }^{170}$ R.R. v Poland ECHR 2011-III 209, para 206; P. and S. v Poland App no 57375/08 (ECtHR, 30 October 2012), para 106.
} 
law may become relevant. In relation to conscientious objection to same-sex marriage, the ECtHR has already ruled that states have a wide margin of appreciation in reconciling freedom from discrimination with freedom of religion. Refusals to accommodate registrars and counsellors with conscientious objections to same-sex marriage do not, according to the ECtHR, violate freedom of religion. ${ }^{171}$ In Grimmark, the Court could leave similar scope for European states - like Sweden - to refuse to tolerate conscientious objections by medical staff to abortion.

Time will tell whether legal intolerance remains a viable response to claims of conscience against abortion in Europe. In the meantime, it is useful to juxtapose Swedish intolerance to the opposite legal response, adopted in Italy. Unlike Swedish law, Italian abortion legislation contains a conscience clause: '[m]edical practitioners and other health personnel shall not be required to assist in ... pregnancy terminations if they raise a conscientious objection'. ${ }^{172}$ The conscience clause is tailored to cover only 'procedures and activities specifically and necessarily designed to bring about the termination of pregnancy'; and thus does not apply to pre- or aftercare. ${ }^{173}$

Nevertheless, as I argue elsewhere, conscientious objection to abortion is more than 'merely' tolerated in Italy. ${ }^{174}$ It is positively respected. Abortion itself, conversely, seems barely to be tolerated. Although women have a (limited) legal right to abortion under Italian law, ${ }^{175}$ practical obstacles drastically restrict effective access, to the point where conscientious objection has become the rule and access to abortion an exception. ${ }^{176}$ Unlike in most countries, in Italy only gynaecologists and obstetricians can perform abortions. ${ }^{177}$ But

\footnotetext{
${ }^{171}$ Eweida $v$ UK ECHR 2013-I 215.

172 Legge No. 194/1978 - Norme per la tutela sociale della maternità e sull'interruzione volontaria della gravidanza (Italy), section 9 (own translation).

173 Ibid.

${ }^{174}$ See reference omitted for review purposes.

175 During the first 90 days of pregnancy, women can apply to a public counselling centre, medical social agency or physician of their choice to request abortion in certain circumstances (eg serious danger to their physical or mental health and foetal malformations). Counselling centres and medical social agencies are required by law 'to examine possible solutions to the problems in consultation with the woman ... to help her to overcome the factors which would lead her to have her pregnancy terminated'. Unless termination is urgent, the woman must also 'reflect for seven days' on her decision to have an abortion. After the first 90 days of pregnancy, abortion is only allowed in exceptional circumstances, including 'serious threat to the women's life'. See ibid, sections 4, 5 and 6 (own translation).

176 Wendy Chavkin, Laurel Swerdlow and Jocelyn Fifield, 'Regulation of Conscientious Objection to Abortion: An International Comparative Multiple-Case Study' (2017) 19 Health and Human Rights 55, 60. In some regions of Italy, women are forced to travel abroad for an abortion. See International Planned Parenthood Federation - European Network (IPPF EN) v Italy Complaint no 87/2012 (ECSR, 10 September 2013), para 192.

${ }^{177}$ Legge No. 194/1978 (n 172), section 8.
} 
the rate of conscientious objection among gynaecologists has been rising steadily, from 59\% in 2005 to $70 \%$ in $2012 .{ }^{178}$ In several regions of the country, including Lazio (the region of Rome) and Sicily, more than $80 \%$ of gynaecologists refuse to perform abortions. ${ }^{179}$ Needless to say, such high rates of conscientious objection hamper effective access to abortion. A key contributing factor is the fact that $85 \%$ of all abortions in Italy are surgical, as opposed to medical. ${ }^{180}$ Because surgical abortions require more direct ('hands-on') medical intervention in the termination of pregnancies, excessive reliance on surgical abortions strengthens the moral case for widespread exemptions to cater for conscientious objectors. ${ }^{181}$ Contrast this, for instance, to Norway, where fewer than $14 \%$ of all abortions are surgical and the rate of conscientious objection among doctors is much lower than in Italy. ${ }^{182}$

In two separate cases, the ECSR has already found the Italian legal framework on conscientious objection to abortion, as it operates in practice, to violate women's right to health. ${ }^{183}$ Although the Committee has noted that 'the high number of objecting health personnel in Italy does not per se constitute evidence' of ineffective implementation, ${ }^{184}$ it has uncovered 'serious problems' in the implementation of the law. ${ }^{185}$ These include a 'significant number of hospitals where, even if a gynaecology unit exists, there are no nonobjecting gynaecologists, or there is just one ... which [risks] the creation of extensive geographical zones where abortion services are not available'. ${ }^{186}$ In practical terms, then, what matters for the ECSR is not the overall rate of conscientious objection in the country, but how local rates of objection affect access to abortion. Once again, though, the same practical factors that also feature in other legal systems - frequency of objections and availability of alternatives - are key.

\footnotetext{
178 IPPF EN (n 176), para 82; Confederazione Generale Italiana del Lavoro (CGIL) v Italy Complaint no 91/2013 (ECSR, 12 October 2015), para 140 (in both cases the complainant organization cites official government reports on the implementation of legge No. 194/1978).

179 Chavkin, Swerdlow and Fifield (n 176) 59-60.

180 IPPF EN (n 176), para 99 (submissions of the Italian government).

181 Things might be changing, however. The region of Lazio, for instance, recently became the first in Italy to promote medical abortions to 'make access to Law 194 the least onerous possible for women'. See Anna Rita Cillis and Maria Novella de Luca, 'La pillola dell'aborto anche in consultorio, rivoluzione nel Lazio' ( $L a$ Repubblica, 5 April 2017) <www.repubblica.it/salute/2017/04/05/news/la_pillola_dell_aborto_ anche_in_consultorio_rivoluzione_nel_lazio-162223561/> accessed 17 August 2018 (own translation).

182 Chavkin, Swerdlow and Fifield (n 176) at 61 (unlike in Italy, no exact data on the rate of objections are available, but Cavkin et al.'s qualitative research indicates that 'objectors constitute a very small minority').

${ }^{183}$ IPPF EN (n 158); CGIL v Italy (n 178).

${ }^{184}$ IPPF EN (n 176), para 168.

185 Ibid, para 169.

186 Ibid.
} 


\section{Conscientious objection to same-sex marriage: The Netherlands and South} Africa

Same-sex marriage is at the heart of contestation over conscientious objection in several countries. ${ }^{187}$ Constitutional democracies that introduce same-sex marriage are likely to face a divisive question: how should the law respond to persons who invoke their religious conscience to refuse to facilitate same-sex marriages? This implicates a range of private individuals, including bakers, florists and photographers. Here, however, I choose to only deal with conscientious objections by public officials. More specifically, I discuss claims of conscience by civil servants against registering same-sex marriage. Only a few constitutional democracies have opted for legal exemptions in responding to these claims. South Africa and the Netherlands provide contrasting approaches. ${ }^{188}$

In the Netherlands, the response to civil servants who refuse to register same-sex marriages was marked by a transition from pragmatic tolerance to principled intolerance. After the introduction of same-sex marriage in 2001, ${ }^{189}$ Dutch civil servants with conscientious objections initially benefitted from a policy of de facto pragmatic tolerance. The same-sex marriage Act itself does not include a conscience clause. But during the parliamentary debate, the Dutch government suggested that municipalities should come up with practical solutions to registrars' claims of conscience. ${ }^{190}$ Under this pragmatic approach, several municipalities introduced administrative systems whereby colleagues took over duties of civil servants who objected to registering same-sex marriages. ${ }^{191}$

Initially, this policy of pragmatic tolerance was widely endorsed, including by the Dutch Equality Commission. ${ }^{192}$ In the decade that followed, however, the legal and political debate gradually shifted from pragmatic tolerance towards principled intolerance. Although successive governments repeated their commitment to the pragmatic solution, individual

\footnotetext{
187 See, among many examples, Masterpiece Cakeshop v Colorado Civil Rights Commission 584 US (2018); Ladele v London Borough of Islington [2009] EWCA Civ 1357. See also the ongoing debate on the need for a religious anti-discrimination act in Australia, in the wake of legalization of same-sex marriage.

188 This section draws on reference omitted for review purposes.

189 Wet van 21 december 2000 tot wijziging van Boek 1 van het Burgerlijk Wetboek in verband met de openstelling van het huwelijk voor personen van hetzelfde geslacht (entered into effect on 1 April 2001).

190 See Equality Commission, Opinion 2002-25, para 2.3 <https://mensenrechten.nl/nl/oordeel/2002-25> accessed 17 August 2018.

191 By 2011, however, 72\% of all Dutch municipalities refused to accommodate civil servants with conscientious objections to same-sex marriage. See MacDougall and others (n 3) 137.

192 Opinion 2002-25 (n 190), para 5.8. See also Equality Commission, Opinion 2002-26, para 5.7, available at <https://mensenrechten.nl/nl/oordeel/2002-26> accessed 17 August 2018.
} 
members of parliament started insisting on stringent limits on the right to conscientious objection of civil servants. ${ }^{193}$ In 2008, the Dutch Equality Commission joined these calls by changing course. ${ }^{194}$ Whereas the Commission had initially favoured pragmatic solutions, it suddenly 'discovered' that in its earlier opinions it had accepted pragmatic tolerance without truly engaging arguments of principle. ${ }^{195}$ On the basis of 'principled arguments', including the distinction between rights-infringing and standard claims of conscience, ${ }^{196}$ the Commission now decided differently. It found that municipalities could not accommodate civil servants who refuse to comply with the law on same-sex marriage, because doing so condones violations of the equality principle. ${ }^{197}$

In 2014, the Dutch legislature finally responded to these political and legal developments by enacting legislation to exclude persons who would violate equality legislation from eligibility for civil service. ${ }^{198}$ The Act's explanatory report acknowledges that ' $[\mathrm{g}]$ iving space to claims of conscience generally fits in the Dutch tradition of tolerance towards different religious opinions'. '[B]ut unfortunately', it continues, 'there are also developments in the Netherlands that oppose that tradition ... The problem is that religions are not always equally tolerant' ${ }^{199}$ In adopting the 2014 Act, the legislature has responded in categorical terms to this (perceived) religious intolerance: 'in a climate of intolerance, what helps is not the mere searching for pragmatic solutions to the consequences of intolerance, but consistently upholding the prohibition of discrimination' ${ }^{200}$

The Dutch legislature thus refused to tolerate civil servants who invoke their conscience to infringe the rights of partners in same-sex couples. ${ }^{201}$ Quite the opposite is true in South Africa. Same-sex marriage was introduced in South African law in the Civil Union Act 2006, as a direct consequence of the Constitutional Court judgment in Minister of Home

\footnotetext{
193 See Equality Commission, Advice 2008/04 at 6 <www.mensenrechten.nl/nl/publicatie/9928> accessed 17 August 2018.

194 Equality Commission, Opinion 2008-40 <https://mensenrechten.nl/nl/oordeel/2008-40> accessed 17 August 2018.

195 Ibid, para 3.10.

196 Ibid, paras 3.26-3.27.

197 Ibid, para 3.27.

${ }^{198}$ Wet van 4 juli 2014 tot wijziging van het Burgerlijk Wetboek en de Algemene wet gelijke behandeling met betrekking tot ambtenaren van de burgerlijke stand die onderscheid maken als bedoeld in de Algemene wet gelijke behandeling, Article 1.2. It should be noted that at the time of enactment of the 2014 Act, only very few civil servants in the Netherlands had conscientious objections to same-sex marriage (88 in total, spread over 48 of the 415 municipalities). See Explanatory report to ibid at 1-2.

${ }^{199}$ Explanatory report to ibid. at 5 (own translation).

${ }^{200}$ Ibid at 6 (own translation).

${ }^{201}$ It should be noted, however, that the 2014 Act only operates towards the future so that currently employed civil servants with conscientious objections to same-sex marriage do not automatically lose their job. Instead, municipalities are left to decide what to do with currently employed civil servants.
} 
Affairs $v$ Fourie. ${ }^{202}$ In Fourie, the Court ruled that lack of legal recognition of same-sex relationships violated the equality provision of the Constitution of South Africa. The Constitutional Court also addressed conscientious objection to same-sex marriage in a few obiter dicta that suggest a strikingly different response from the one I have proposed in Section 2. The Court for instance dismissed any analogy to interracial marriage: 'it would be wrong and unhelpful to dismiss opposition to homosexuality on religious grounds simply as an expression of bigotry to be equated to racism'. ${ }^{203}$ The Court further indicated that objections could be dealt with through reasonable accommodation:

[t]he principle of reasonable accommodation could be applied by the state to ensure that civil marriage officers who had sincere religious objections to officiating at samesex marriages would not themselves be obliged to do so if this resulted in a violation of their conscience. ${ }^{204}$

As Elsje Bonthuys has noted, 'Parliament eagerly seized upon the idea' to include a conscience clause in section 6 of the Civil Union Act. ${ }^{205}$ Under section 6, a

marriage officer ... may in writing inform the Minister that he or she objects on the grounds of conscience, religion and belief to solemnising a civil union between persons of the same sex, whereupon that marriage officer shall not be compelled to solemnize such civil unions. ${ }^{206}$

The parliamentary debate on the Civil Union Act is largely silent on why the conscience clause was included in the Act, although a minor party did allege that the African National Congress only inserted the clause for strategic reasons of compromise, 'in order to appease both sides' ${ }^{207}$ One way to understand the conscience clause, then, is in terms of pragmatic tolerance to appease conservative opponents of same-sex marriage. The clause may have served the pragmatic aim of ensuring sufficient buy-in for the morally divisive introduction

\footnotetext{
202 (2005) ZACC 19.

203 Ibid, para 91.

${ }^{204}$ Ibid, para 159.

${ }^{205}$ Elsje Bonthuys, 'Irrational Accommodation: Conscience, Religion and Same-Sex Marriages in South Africa Note’ (2008) 125 South African Law Journal 473, 474.

206 Civil Union Act 2006, section 6.

${ }^{207} \mathrm{Mr}$. L.W. Greyling, speaking for the Independent Democrats (ID) during the plenary reading of the Civil Union Bill on 14 November 2006: 'What has shocked the ID, however, has been the attitude of the ANC ... Instead of showing true leadership, they chose to compromise on constitutional principles in an effort to appease both sides.' See $<$ https://biblio.wiki/wiki/National_Assembly_debate_on_the_Civil_Union_Bill $>$ accessed 17 August 2018.
} 
of same-sex marriage in South African law, by explicitly tolerating conscientious objections to same-sex marriage. ${ }^{208}$

Another way to understand the conscience clause, however, is not as an instrument of (negative) tolerance, but as signalling (positive) respect for registrars' conscience in South African law. Under section 6 of the Civil Union Act, exemptions are granted automatically. Upon informing the Minister of their objection, marriage officers 'shall not be compelled' to marry same-sex couples. There is no room for a sincerity review, nor for limitations (including checks on the numbers of objectors). ${ }^{209}$ Under the conscience clause, nearly $40 \%$ of all marriage officers in South Africa are now officially exempt from their legal duty to solemnize same-sex unions. ${ }^{210}$ Polls further indicate that, in practice, fewer than $30 \%$ of marriage officers in South Africa are willing to marry same-sex couples. ${ }^{211}$ In line with conscientious objection to abortion in Italy, such widespread objections are bound to generate serious obstacles to access to same-sex marriages, especially in rural areas (and since samesex couples can, for obvious reasons, not turn to religious officials to get married). ${ }^{212}$

\section{Conclusion}

It is tempting, as the relevant literature shows, to evaluate claims of conscience in normative terms. The normative claim can be that complicity-based claims of conscience should not be tolerated, because they cause dignitary harm. Or it can be the converse: sincere conscientious objections should be respected, so as not to compromise the integrity of the religiously devout. But before we even engage in such normative disagreement, we do well to recognize the existence of a practical baseline that delineates the realm of possible legal responses. The practical baseline is composed of at least two factors: availability of alternative duties and

\footnotetext{
${ }^{208}$ Other factors lend some credence to this hypothesis. For instance, as the Constitutional Court noted in Fourie, same-sex marriage could have been introduced through a simple textual amendment of the Marriage Act 1961. Instead, the South African Parliament introduced it through a separate piece of legislation, which avoided the term 'marriage' in its title. See MacDougall and others (n 3) 131 ('the creation of separate legislation to cater for same-sex marriage is arguably motivated by the desire to maintain a form of marriage which would be acceptable to the Christian majority in South Africa').

${ }^{209}$ Helen Kruuse, 'Conscientious Objection to Performing Same-Sex Marriage in South Africa' (2014) 28 International Journal of Law, Policy and the Family 150, 163.

${ }^{210}$ Carl Collison, 'Home affairs minister rejects call to amend discriminatory same-sex law' (Mail \& Guardian, 19 July 2017) <https://mg.co.za/article/2017-07-18-home-affairs-minister-rejects-call-to-amend-discriminatorysame-sex-law> accessed 17 August 2018. See also Kruuse (n 76).

${ }^{211}$ Carl Collison, 'Less than a third of home affairs officials are willing to marry same-sex couples' (Mail \& Guardian, 15 September 2016) <https://mg.co.za/article/2016-09-15-00-409-home-affairs-offices-only-117have-officials-willing-to-marry-same-sex-couple> accessed 17 August 2018.

${ }^{212}$ See Bonthuys (n 205) 477; Kruuse (n 209) 163.
} 
frequency of objections. ${ }^{213}$ Both factors are prominent in the literature. ${ }^{214}$ They have also and more crucially - surfaced time and again in the comparative discussion in this article. Both factors are central to how the law has responded to conscientious objections across constitutional democracies.

In their interaction, both factors set a practical baseline below which there is arguably no room for exemptions for conscientious objectors. Hence, below the baseline it is redundant to engage in normative disagreement. The reason for this redundancy resides in how interaction between both practical factors delineates the possible realm of legal solutions.

First, both factors necessarily act in conjunction to enable or disable conscientious exemptions. The availability of alternative duties, in particular, is a practical precondition to exempting conscientious objectors from their general duty to obey the law. When no alternative duties are available, there should arguably be no exemption. This explains why constitutional democracies do not grant exemptions for conscientious objectors who refuse to pay general taxes. Because of the way tax systems operate - collecting contributions from a large proportion of the population to fund a wide range of government expenses and public services - it is impossible to devise practical systems that would allow objectors to comply with their conscience, while simultaneously carrying an alternative burden under the law. ${ }^{215}$

Second, the interaction of both factors - availability of alternative duties and frequency of objections - can either remove or impose practical limits on conscientious exemptions. Their interaction removes limits to exemptions when frequency of objections is low. Low rates of objection enable a system of alternative duties to function without compromising the legal rights of others or the public interest. We see this process play out most clearly in relation to conscientious objection to military service. Here, the Constitutional Court of the Republic of Korea has recognized that, since the number of conscientious objectors in the country is very low, introducing alternative civilian service cannot possibly jeopardize national security. From a pragmatic perspective, introducing alternative service is

\footnotetext{
213 There may well be other relevant practical factors, but these are the two factors that transpire from the comparative discussion in Section 3.

${ }^{214}$ Schlink (n 41) 102 and 104 ('the freedom to object for conscientious reasons is premised on the assumption that not everybody will make use of this waiver' and 'someone who refuses to fulfil one particular obligation can be required to fulfil an alternative obligation'); NeJaime and Siegel (n 1) 2585 ('[t]he feasibility of providing alternative access to services may depend on the availability of other willing providers').

${ }^{215}$ Schlink (n 41) 105 ('there is no substitute ... for the taxes that some pacifists refuse to pay').
} 
even preferable to sentencing conscientious objectors to prison, in that it 'provide[s] more efficient ways to accomplish public interests than just imprisoning the objectors' ${ }^{216}$

But the interaction between both factors can also impose limits on exemptions. This occurs when conscientious objections are so frequent as to fundamentally undermine the practical operability of any system of alternative duties. We see this scenario play out most clearly in relation to conscientious objection to abortion in Italy and to same-sex marriage in South Africa. In both contexts, referral systems fail to function in practice - at least in certain localities - due to exorbitant rates of objection. When $80 \%$ of gynaecologists or $70 \%$ of marriage officers refuse to perform abortions or marry same-sex couples, practical alternatives are no longer feasible. Thus, interaction between availability of alternative duties and frequency of objections sets a practical baseline that, in certain circumstances, imposes limits on the feasibility of exemptions.

Whenever exemptions are not practically feasible, it is redundant to engage in normative disagreement on either (in)tolerance of or (dis)respect for claims of conscience. This applies, among others, to my own normative argument on tolerance for conscientious objections by doctors against performing abortions. Above the practical baseline, however, there remains room for reasonable disagreement. Here, as Lorenzo Zucca points out, prudential reasons can be trumped by principled reasons. ${ }^{217}$ Above the baseline, how far constitutional democracies go in exempting religious objectors depends on the importance lawmakers and courts attach to arguments of principle. The legal response to conscientious objection to same-sex marriage in the Netherlands is instructive. Although only few Dutch civil servants objected to registering same-sex marriages, the legislature intervened to put an end to the practical system of reasonable accommodation. It did so to firmly uphold the principle of equality.

I have argued, along similar principled lines, that conscientious objection by civil servants to same-sex marriage should not be tolerated, because they cause partners in a samesex couple expressive harm. Others may disagree - and have disagreed - with these normative arguments. But we do well to recognize that our normative disagreements on these and other claims of conscience are only viable when we find ourselves above the practical baseline. Below that baseline, practical factors supply all the answers we need.

\footnotetext{
${ }^{216}$ Case on Conscientious Objectors (n 134).

${ }^{217}$ Lorenzo Zucca, 'Is there a Right to Conscientious Objection?' in Susanna Mancini and Michel Rosenfeld (eds), The Conscience Wars: Rethinking the Balance between Religion, Identity, and Equality (CUP 2018) 143.
} 
